\title{
Nodal wear model: corrosion in carbon blast furnace hearths ${ }^{(\cdot)}$
}

\author{
L.F. Verdeja*, R. González**, A. Alfonso* y Mª .F. Barbés*
}

\begin{abstract}
Criterions developed for the Nodal Wear Model (NWM) were applied to estimate the shape of the corrosion profiles that a blast furnace hearth may acquire during its campaign. Taking into account design of the hearth, the boundary conditions, the characteristics of the refractory materials used and the operation conditions of the blast furnace, simulation of wear profiles with central well, mushroom and elephant foot shape were accomplished. The foundations of the NWM are constructed considering that the corrosion of the refractory is a function of the temperature present at each point (node) of the liquid metal-refractory interface and the corresponding physical and chemical characteristics of the corrosive fluid.
\end{abstract}

Keywords Chemical corrosion of materials. Nodal Wear Model (NWM). Blast furnace hearth. Wear simulation. Tribology.

\section{Modelo de desgaste nodal: corrosión en el crisol del horno alto}

\begin{abstract}
Resumen
Se aplican los criterios del Modelo de Desgaste Nodal (MDN) para la estimación de los perfiles de corrosión que podría ir adquiriendo el crisol de un horno alto durante su campaña. Atendiendo al propio diseño del crisol, a las condiciones límites de contorno, a las características del material refractario utilizado y a las condiciones de operación del horno, se consiguen simular perfiles de desgaste con "pozo central", con "forma de seta" ó de "pie de elefante". Los fundamentos del MDN se apoyan en la idea de considerar que la corrosión del refractario es función de la temperatura que el sistema pueda presentar en cada punto (nodo) de la intercara refractario-fundido y de las correspondientes características físico-químicas del fluido corrosivo.
\end{abstract}

Palabras clave Corrosión química de materiales. Modelo Desgaste Nodal (MDN). Crisol de horno alto. Simulación de los procesos de desgaste. Tribología.

\section{INTRODUCTION}

Traditionally, the corrosion problem of refractories and ceramics has been studied under purely phenomenological criterions (corrosion tests using aggressive liquids and gases), or analyzing very specific aspects of the process, frequently avoiding a more global exposition of this situation and its relation to the dynamics that a daily fabrication process requires ${ }^{[1-3]}$.

Certainly, the variables involved in the process are numerous and the mechanisms cooperating in the refractory degradation-erosion or soft wear, abrasion, chemical attack, adhesion-accretions and thermal wear (thermal shock)-make the simplification of the problem difficult.
The scarce repercussion that abrasive mechanisms have in texts that treat the problem is very noticeable ${ }^{[4-6]}$. At essentially qualitative levels, abrasion is recognized as responsible for the deterioration of materials in the throat, collectingvat (stack) and certain zones of the blast furnace bosh. On a similar way, cooperation of abrasion wear mechanism in blast-furnace trough, metals runner, slag drains and lines due to the presence of particles emulsified in the melt, may be notorious.

On the other hand, it is not common to find corrosion equations (depth of degraded material per time unit) for materials worn out by abrasive mechanism as a function of temperature, pressureshear stress, Young modulus, mass density, attack angle or relative size of the confronted tribological

(•) Trabajo recibido el día 25 de julio de 2002 y aceptado en su forma final el día 10 de marzo de 2003.

$\left(^{*}\right)$ Cátedra de Siderurgia, E.T.S.I.M.O.,Dpto. de Ciencia de los Materiales e Ingeniería Metalúrgica. Universidad de Oviedo, Spain, Independencia 13, Oviedo 33004, Tel. (34) 985 10-43-03, Fax. (34) 985 10-42-42, Email: Ifv@etsimo.uniovi.es

(**) Escuela de Ingeniería, Universidad Panamericana, México, Augusto Rodín 498, 03920 México D.F. México. Tel. (52)55-5563-16-20, Fax. (52)555482-16-00 ext.5230,Email: robglez@mx.up.mx 
Nodal wear model: corrosion in carbon blast furnace hearths L.F. Verdeja, R. GonzÁlez, A. Alfonso y Ma $M^{a}$.F. BARBÉs

pairs. Neither frequent are equations for chemical corrosion, which traditionally have been presented to interpret liquid (metal-slag) refractory interaction. In most cases, the mechanism responsible for the refractory corrosion is assumed at a laboratory scale, by the chemical attack of the refractory constituents (matrix and disperse) by the corrosive fluid. This circumstance has been exploited traditionally in the scientific field by means of laboratory corrosion tests (finger tests), either in static or dynamic mode:

- The cylindrical sample submerged in the corrosive liquid.

- The carved crucible made on the sample of material in order to put the melt inside.

The specific characteristics of each finger test along with the great variety or corrosive fluids offers basic research a wide spectrum of experimental possibilities. Nevertheless, the experimental conditions of the refractory with the corrosive medium in laboratory tests, are far from identifying with the conditions of the material under service. Normally, the finger test results are prone to report corrosion rates much higher than the ones observed in daily industrial practice. One of the contributions of the NWM and its nodal temperatures is to quantitatively manifest the differences between laboratory tests and industrial practice $^{[7]}$.

In many occasions, attempts have been made to express quantitatively the corrosion rate of a material as a function of temperature, nature of the corrosive medium, and velocity of relative displacement of reaction interfaces.

A common factor in all corrosion equations proposed in the scientific literature until now, is admitting that the refractory corrosion by the corrosive fluid occur in a uniform way in absence of singularities (differential corrosions), as it is shown in figures 1 and $2^{[8-11]}$.

The NWM pretends, when the controlling mechanism is of chemical nature, explaining the differential corrosion observed on the hearth of the blast furnace for the production of pig-iron in a quantitative manner as well as all those points of triple contact (metal-slag-gas) present in melt transport spoons, tundish, or casting channels (Fig. 1). The corrosion rate, according to the NWM, not only depends on the temperature differences that exist at the corrosion interface (nodal temperature difference) but also on the

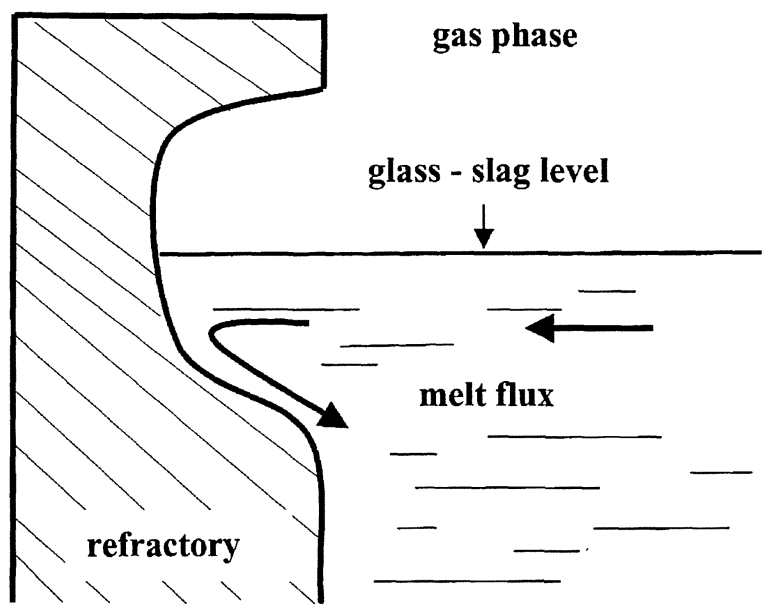

Figure 1. Differential corrosion in refractory-gas-melt triple points.

Figura 1. Corrosión diferencial en puntos de contacto triples: gas - refractario - fundido.

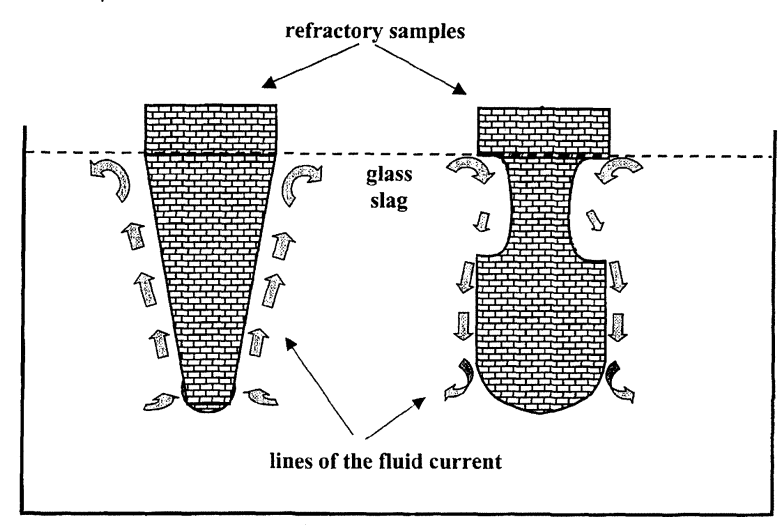

Figure 2. Wear profiles some refractory samples may acquire in contact with melts.

Figura 2. Perfiles de desgaste que se pueden presentar en refractarios que contactan con fundidos.

gradient manifested between the refractory and the temperature of the melt (variable that may be measured experimentally). According to the "Nodal Wear Model", the presence of these thermal gradients may be interpreted as a consequence of different corrosion mechanisms responsible for the material wear, that condition its possible industrial application.

It happens in the same way during the solidification process of a melt (metal, ceramic or slag) at the solidificated melt-mould interface, an interfacial resistance to heat transfer appears related to the superficial energy of the phases in contact. According to the NWM, in the corrosion process of a ceramic, another interfacial resistance 
appears, associated to different corrosion mechanisms that may control the process during the refractory wear

As a consequence of applying the NWM to the chemical degradation of a ceramic, defining the corrosion equation as a function of the following variables is necessary:

- Temperature nodal gradient at the interface of the refractory in contact with the melt.

- Structural characteristics of the matrix and the disperse constituent of the ceramic.

- Transport properties of the fluid and the species being attacked.

A particular case would be the study of corrosion in carbon-based materials in contact with pig-iron, just as it may happen in the "thermic solution" proposed for the design and construction of blast furnace hearths. At table I there are shown the corrosion equations proposed by the NWM for carbon-based materials in contact with pig-iron in case the temperature difference between nodes is higher or lower than one Kelvin degree [12-15].

Another characteristic of the NWM applied to the corrosion process of a solid-fluid controlled by chemical mechanisms, is the resistance to heat transport produced in each of the interface nodes. The obtention of different nodal temperatures along the refractory interface in contact with the melt is possible if the boundary conditions of the problem are defined. FEM commercial programs (Cosmos/Ansys) are used just as service instruments in order to find solutions to the stated thermal problem. One of the boundary conditions refers to the heat transport between the corrosive melt and the refractory. The convective heat transport coefficient, $h_{c}$, is a nodal property. Nevertheless, along many nodes from the wall or the bottom of the blast furnace hearth, the value of may remain constant. The NWM incorporates correlations which are used in calculating the heat transport coefficients between fluids and horizontal or vertical walls, carefully being aware that the concept of linear characteristic dimension that traditionally appears in the Grashof ${ }^{[16-18]}$ number, must be modified. The adaptation of the developed correlations by the heat transport theory to the NWM demand that the linear characteristic dimension of the Grashof number identifies with the thickness of the limit thermic layer of velocities at each one of the nodes of the solid-melt interface, $\delta(T$, nodal $x / y)$.
The value of the thermic nodal limit layer is calculated based on the values that the velocity nodal limit layer, $\delta(v$, nodal $x / y)$ reaches and that according to the NWM, may be determined accurately based on the flotation velocity of the fluid between node " $i$ " and the adjacent " $i-1$ " or by the density difference between node " $i$ " and the melt [10 and 16$]$. In any case, the Grashof number along the wall or the bottom of the hearth would be the same because $\delta(T$, nodal $x / y)$ and $\Delta \mathrm{T}$ are inversely proportional: a bigger thermic gradient $\Delta \mathrm{T}$, means a thinner nodal temperature limit layer.

The consistency of Grashof along the bottom or walls of the hearth of a blast furnace, may be altered in the following specific situations: the zone with inactive coke (deadman) is supported along the bottom or existing coke free region around the hearth corners. In general, the Grashof is the same along the wall or the bottom of the hearth, though $\delta(T$, nodal $x / y)$ and $\Delta T$ for each of the nodes at the interface may have a singular value. The general lines of the calculation process to estimate the resistance to heat transport along the corrosion interface are shown in table ${ }^{[19]}$.

\section{MODEL RESULTS}

A section of the hearth in the blast furnace is shown in figure 3 , over which the NWM will be applied in order to determinate the evolution of corrosion profiles during its work campaign. The

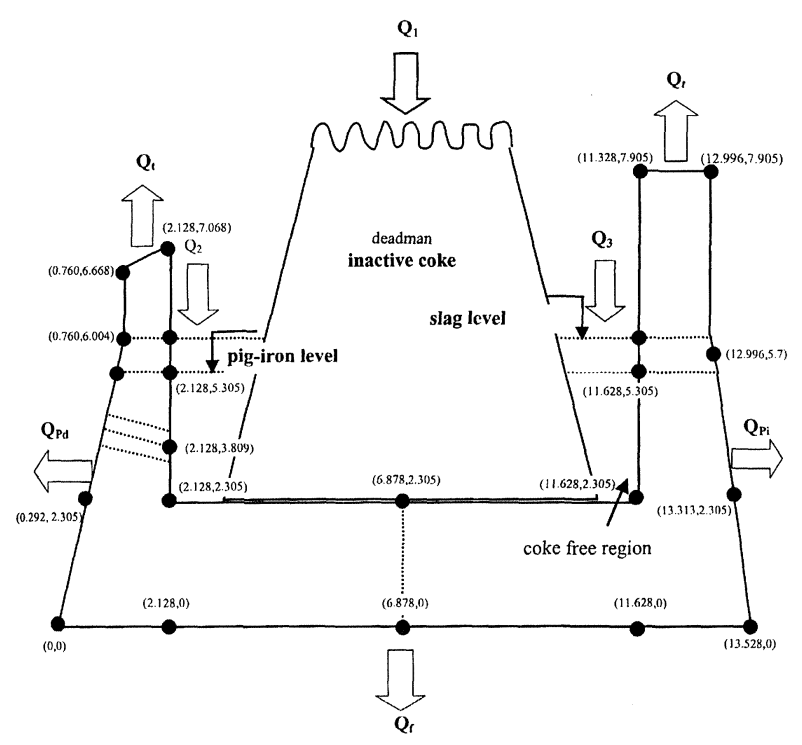

Figure 3. Geometric characteristics of a $4000 \mathrm{t} /$ day production blast furnace hearth.

Figura 3. Características geométricas del crisol de un alto horno de $4000 \mathrm{t}$ /día de producción. 


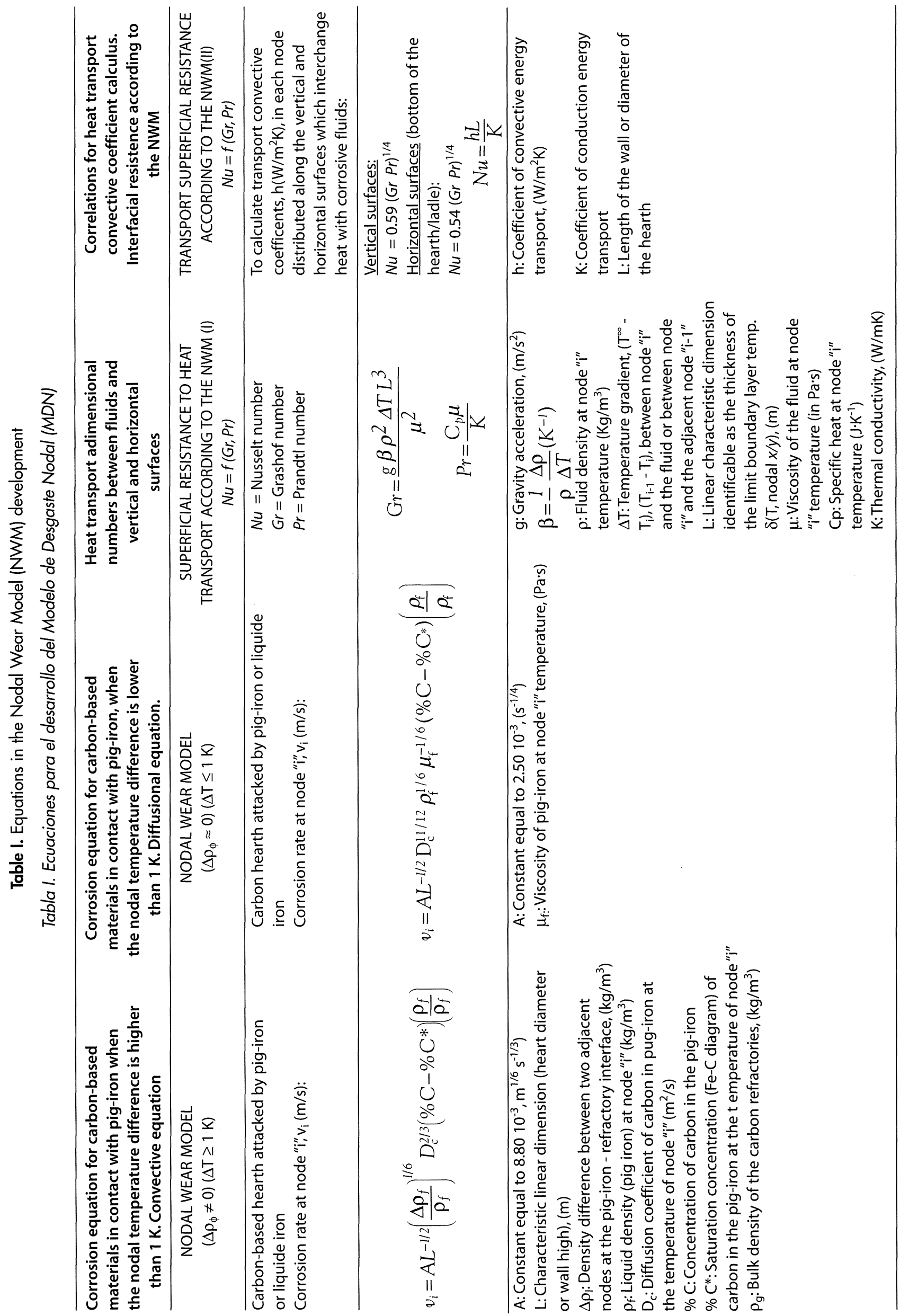


pig-iron production in a hearth with such characteristics may reach is of $4000 \mathrm{t} / \mathrm{day}^{[20]}$.

The calculation of wear that a hearth designed with carbon-based materials suffers, during the campaign of the furnace, is made following these steps:

- Solution of the heat transport differential equation in stationary state for the hearth using finite element, under specific boundary conditions, so the nodal temperatures at the wear zone (pig-iron - refractory contact) are obtained.

- Calculation of corrosion, table I, experienced by each node at the interface. Situation of the wear profile after two days, one weak or six months of operation.

- As the geometry of the hearth at the pig-iron carbon interface is modified, it is necessary to calculate again the nodal temperatures at the wear zone after two days, one weak or six months of operation.

- Repeat succeedingly the determination of the wear profile and the distribution of nodal temperatures at the pig-iron - carbon blocks interface, along the following periods of time: one year, year and a half, two years, two years and a half, three, four, five, six, seven, eight, nine, ten, eleven and twelve years.

The boundary conditions used in some of the simulations are shown in tables II and III. Basically in table II, different limit conditions under which a carbon-based isotropic hearth with average conductivity of $18 \mathrm{~W} / \mathrm{m}^{2} \mathrm{~K}$ could work, have been summarised. On the other hand, some boundary conditions under which an anisotropic carbon hearth may operate are indicated in table III. With these models, tables II and III, the intention is to manifest the influence of different options when installing the carbon based blocks-bricks in the blast furnace hearth. On materials uniaxially compacted, thermal conductivity changes with direction. Only hot isostatic pressing guaranties isotropic.

The erosion profile with "central well" (test HA5-4) may be seen in figure 4, while other profiles represent the "elephant foot" erosion type as obtained by the HA5-5A test in figure 5 (the boundary conditions in test HA5-5A are the same as in HA5-5, except that in all the nodes around the corners $h_{c}=140 \mathrm{~W} / \mathrm{m}^{2} \mathrm{~K}$, equivalent distance of one meter). Finally, also a situation of differential wear at the wall, "mushroom shape" is represented in figure 6 , with passivity on the bottom (its important to emphasis the deepness reached by erosion at one meter bellow the casting taphole of the furnace).

From an energetic point of view, the wear of the hearth provokes a volume increment and, therefore, a potential increment in the production capacity of the furnace. Consequently, raising the production capacity as well as maintaining the casting rate of the beginning of the campaign, the refrigeration needs to increase along the operative cycle. For example, in the HA5-5 test, heat losses through the hearth and nozzles of the furnace (between 30 and $40 \%$ of the total heat losses of the blast furnace) would be of $380106 \mathrm{~kJ} / \mathrm{d}$ at the beginning of the campaign while after twelve years they would be of $53010^{6} \mathrm{~kJ} /$ day ${ }^{[16}$ and 17$]$.

\section{DISCUSSION}

The variables that influence the wear of a hearth in a blast furnace may be grouped in four categories:

- The design of the hearth: criteria for the position of materials, dimensions of wall and bottom, verticality of the walls or existence of transition zones in form of steps between the wall and the bottom of the hearth ${ }^{[21-23]}$.

- The operation conditions for the furnace: casting temperature, composition of the pigiron, operation with central or lateral flux of reduction gases, dimensions of the inactive coke (deadman) zone or if this zone does rest or not on the bottom of the hearth ${ }^{[24-27]}$.

- The boundary conditions: the nature (water or air), temperature and flux of the cooling media determinates the values of the convective heat transport coefficients, $h_{c}$, that may be reached $\left(100 \mathrm{~W} / \mathrm{m}^{2} \mathrm{~K}\right.$ for air and $3000 \mathrm{~W} / \mathrm{m}^{2} \mathrm{~K}$ for water) ${ }^{[16-18]}$.

- The physical, chemical and mechanical characteristics of the refractory: porosity, resistance to aggressive media, thermal conductivity, expansion coefficient, compression strength and creep resistance.

The main contribution of the NWM, is to consider in its simplest formulation, most of the mentioned variables and quantifying the influence they have over the corrosion profile form in the hearth along the campaign.

It is frequently mentioned the difficulty to interpret the results of laboratory corrosion tests due to the numerous variables involved in the process. The NWM may contemplate all the 


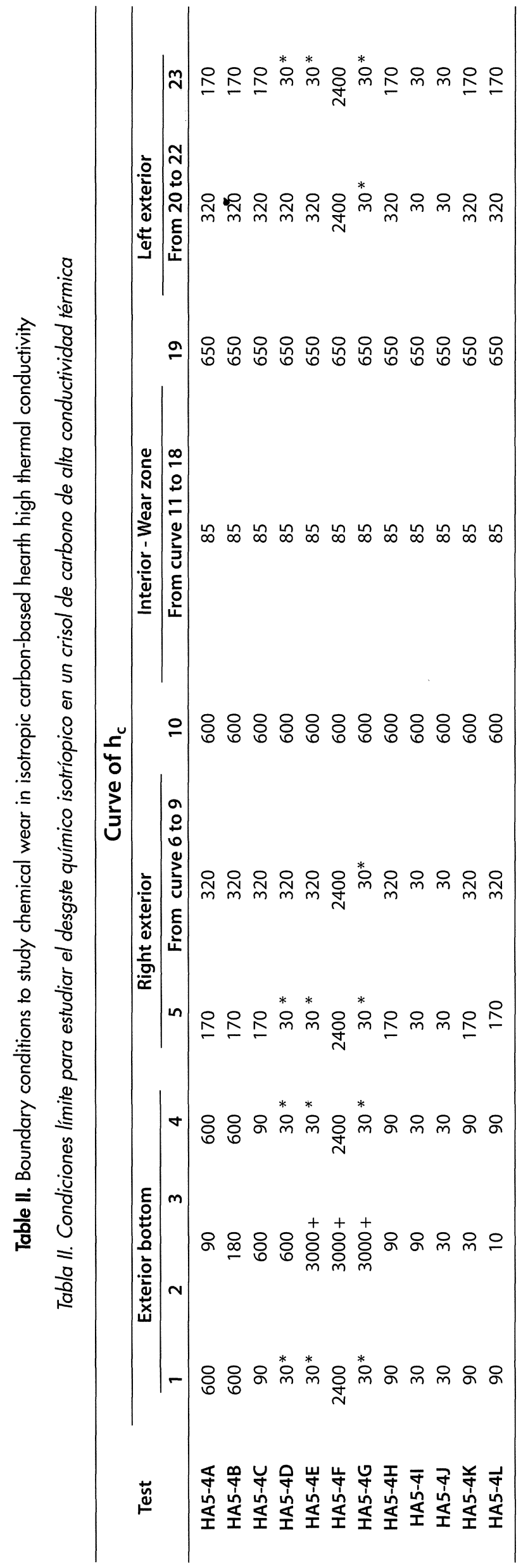

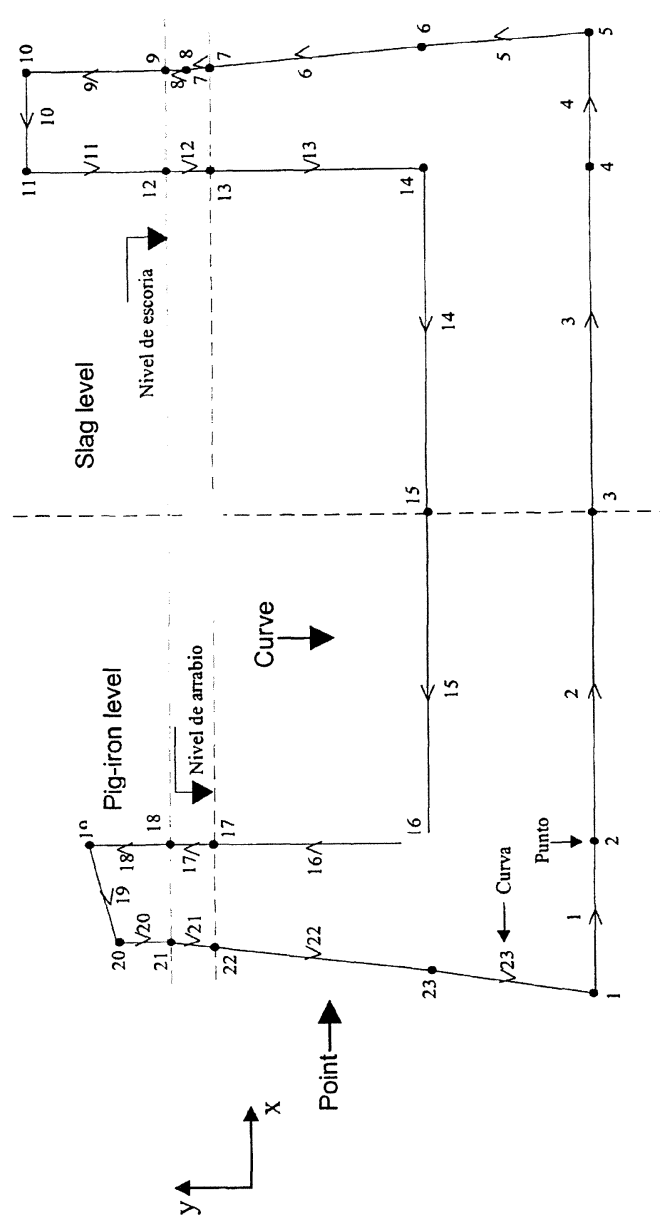

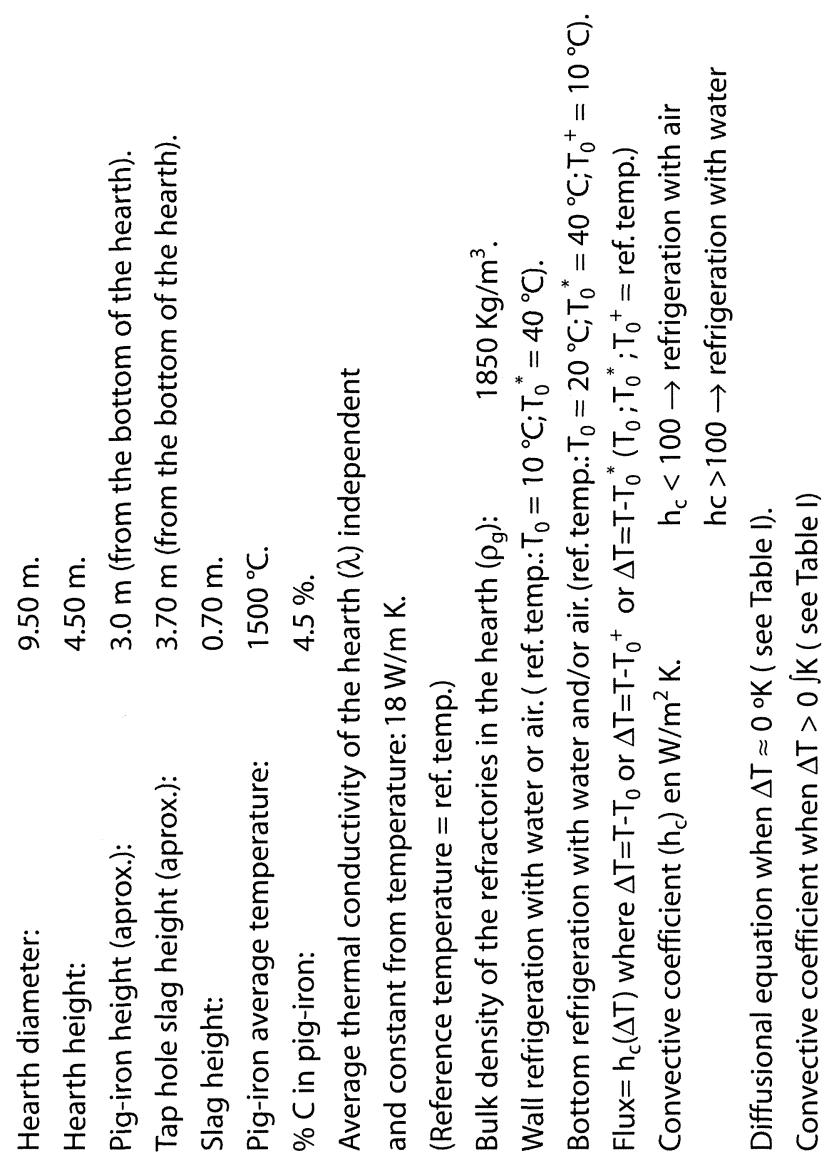

Rev. Metal. Madrid 39 (2003) 183-192

(c) Consejo Superior de Investigaciones Científicas Licencia Creative Commons 3.0 España (by-nc) 


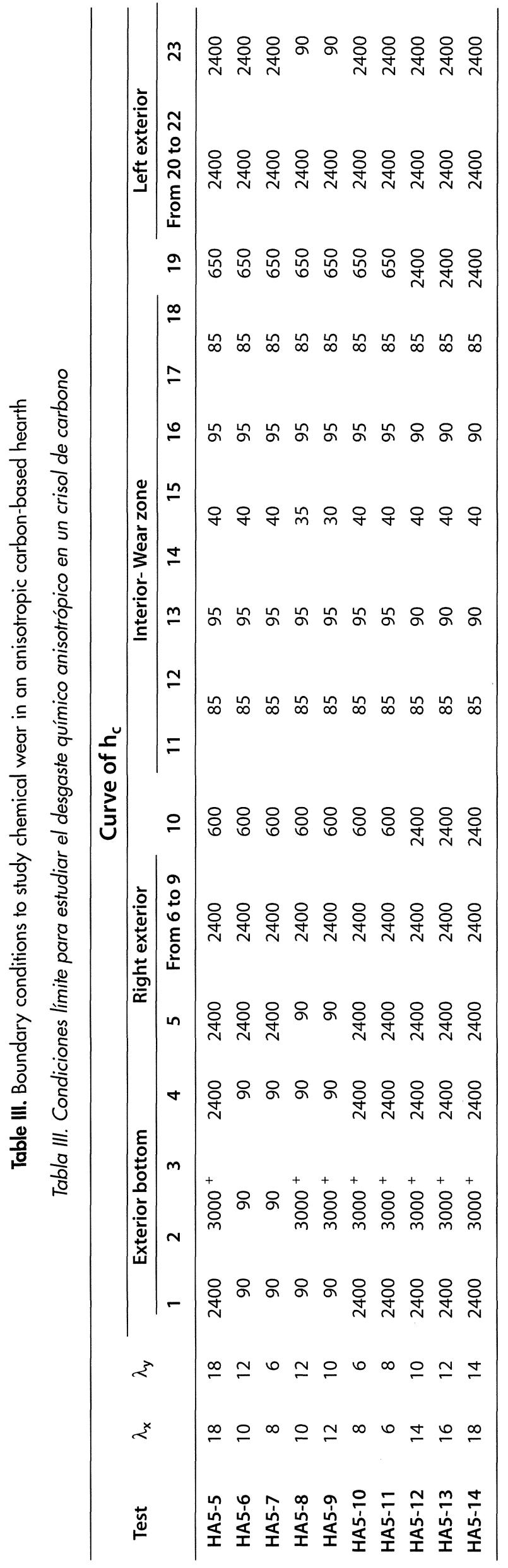

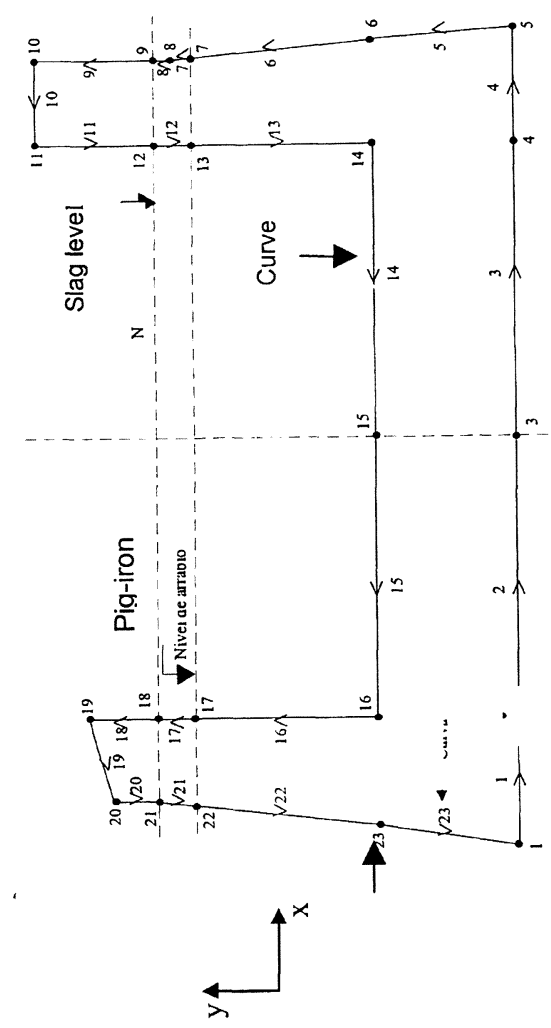

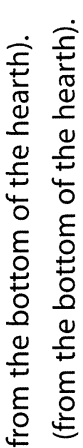

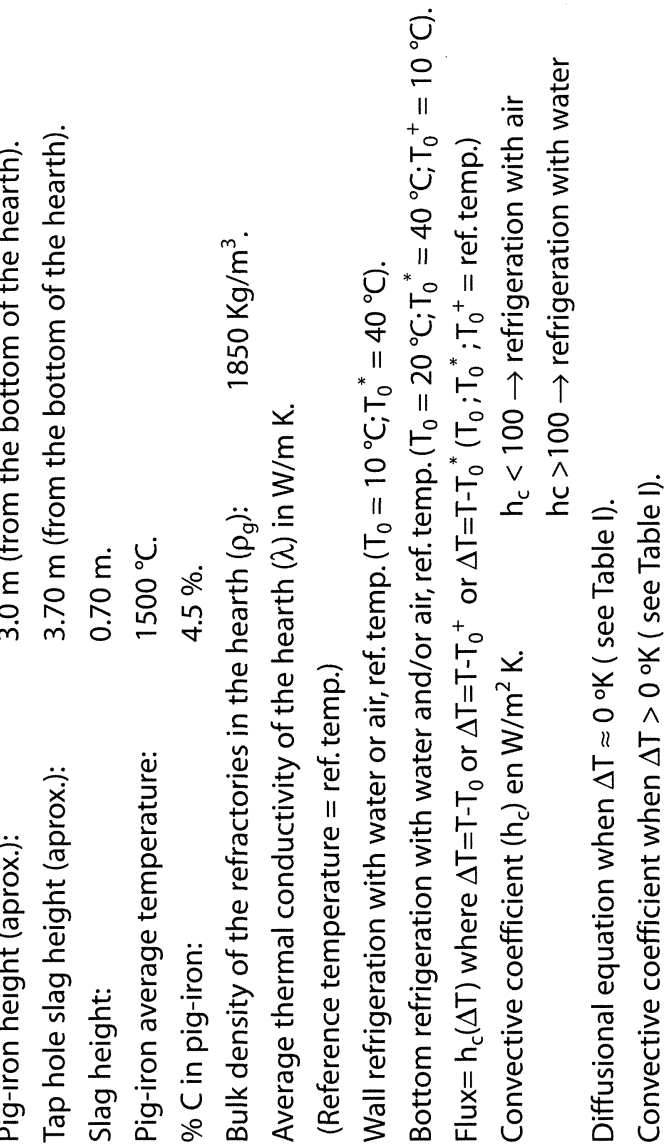

Rev. Metal. Madrid 39 (2003) 183-192 


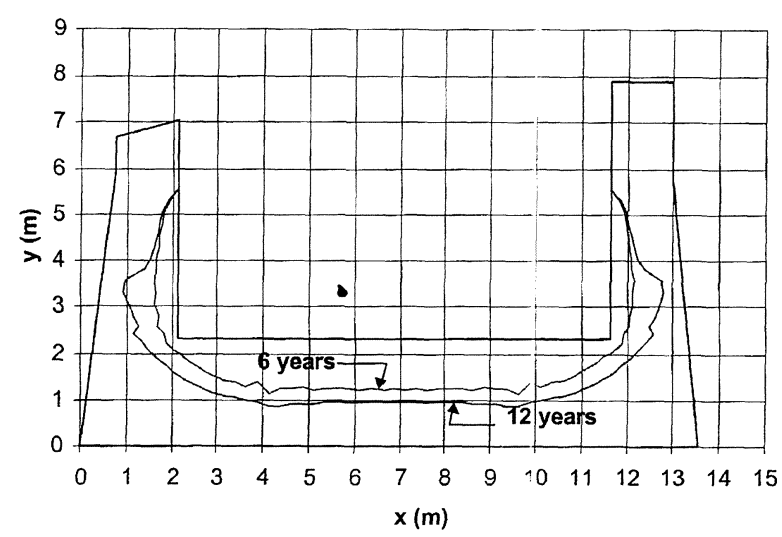

Figure 4. "Central well" corrosion profile for an isotropic carbon-based hearth working with the boundary conditions indicated in test HA5-4A.

Figura 4. Perfil de corrosión de "pozo central" en un crisol carbonoso bajo las condiciones operativas indicadas por el ensayo HA5-4A.

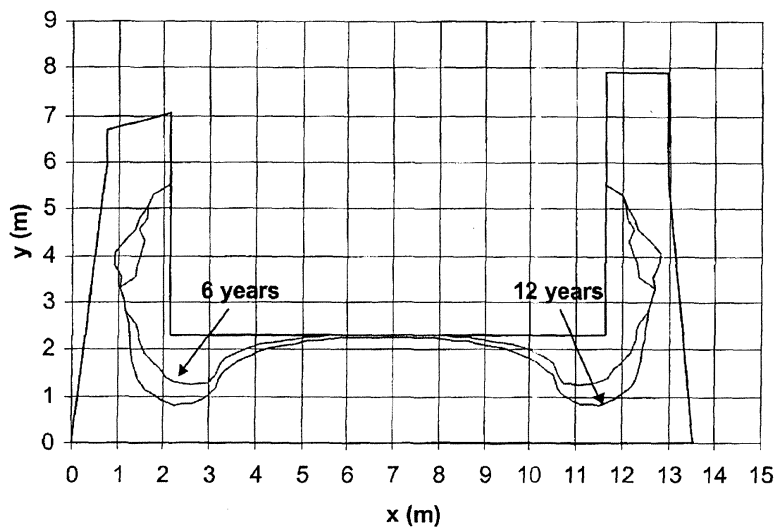

Figure 5. "Elephant foot" corrosion profile for an isotropic carbon-based hearth working with the boundary conditions indicated in test HA5-5A.

Figura 5. Perfil de corrosión "huella de elefante" en un crisol carbonoso que trabaja bajo las condiciones operativas indicadas por el ensayo HA5-5A.

variables influencing the process and allowing seeing that the "same quality" may suffer more or less wear as a function of the position that occupies inside the hearth.

With low cooling conditions in isotropic carbonbased hearths with high conductivity, the perforation of the bottom (HA5-4L test, Table II) or the lateral walls (HA5-4G test, Table II) is provoked when the furnace has not yet reached a six-year functioning period. On the other hand, due to the geometric characteristics of the hearth, figure 3 , constructing with materials of low and medium conductivity bears

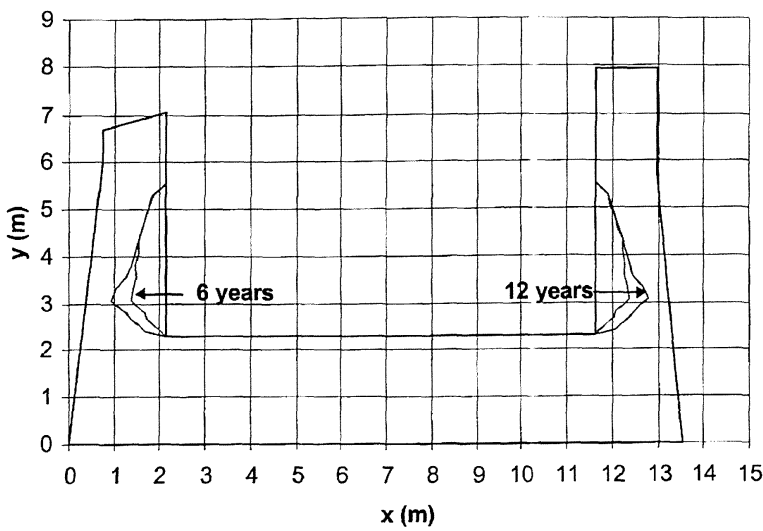

Figure 6. Corrosion profiles, with pronounced differential wear at the wall ("mushroom shape"), for an isotropic carbon-based hearth working with the conditions indicated in test HA5-5.

Figura 6. Perfil de corrosión "tipo seta" en el crisol carbonoso de un alto horno que trabaja con las condiciones operativas indicadas por el ensayo HA5-5.

the risk of perforation at the wall after the second year of campaign even when using extreme cooling conditions at the walls as well as at the bottom of the hearth (HA5-10 test, table III).

The formation of an "elephant foot" or central well profile, is connected in the literature to the fact that the inactive coke zone of the furnace may or may not lean on the bottom of the hearth ${ }^{[21]}$. According to the NWM, the consequence of the deadman leaning on the base of the hearth is translated in a raise in heat transport resistance (low $h_{c}$ values) at the surface of the refractory in contact with the deadman, while at the corners, a raise in the convective transport coefficient is provoked for all the nodes of the pig-ironrefractory interface.

Changes in the operation of the furnace may be programmed in a way that, though during the first instants an "elephant foot" furnace profile is formed, this physiognomy is transformed with time in a central well wear profile (HA5-14B exercise, were boundary conditions are similar to those of HA5-14 test, Table III, except the $h_{c}$ variable experiences variations at the bottom and walls of the hearth during the work campaign of the furnace), (Fig. 7).

The NWM may be an adequate instrument to explain differential corrosions appearing in some refractory samples submitted to corrosion tests by immersion, (Fig.2), (Taylor vortice ${ }^{[28]}$ or, in opinion of the authors, a consequence of the Marangoni effect). The paradox emerges when corrosion at the gas-refractory-liquid interface is more pronounced at 


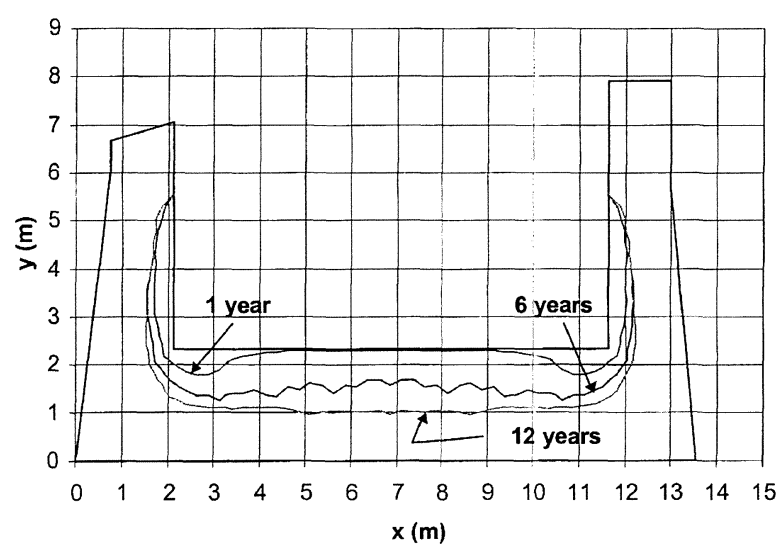

Figure 7. Evolution of corrosion profiles in test HA5-14B.

Figura 7. Evolución de los perfiles de corrosión para el ensayo HA5-14B.

low temperature, due exclusively, to the very intense rotation speed of the samples in the melt under these conditions. The chemical wear rate is directly proportional to the nodal temperature and to the temperature difference between the considered node and adjacent nodes. In a gas-refractory-liquid interface, figures 1 and 2, the thermal gradient at the refractory is normally high, but the temperature level reached at the nodes in the proximity of the triple point is not very important. The small size of the linear characteristic dimension of the sample and the high rotation speed may provoke the nodal resistance to heat transport in the nodes near the gas-refractory-liquid interface to disappear (Fig. 8). These two effects make the wear more intense at the nodes near to the interface than at those sufficiently far (nodal thermic gradients tending to zero).

Finally, the NWM, constitutes a complement of all those algorithms developed to estimate, starting from temperature measurements or heat flux, the corrosion profile of a hearth in a blast furnace during its campaign ${ }^{[29-31]}$. The thickness reached by the temperature nodal boundary layer $\delta(T$, nodal $x / y$ ) is normally lower than a centimeter, by which, the wear profile calculated by the NWM will substantially agree with those methodologies which pretend identifying the isotherms obtained by resolving heat transport equations with those experimentally obtained.

\section{CONCLUSIONS}

The NWM may represent a valuable contribution in understanding the mechanisms of chemical wear that different materials may experience in contact with a melt.

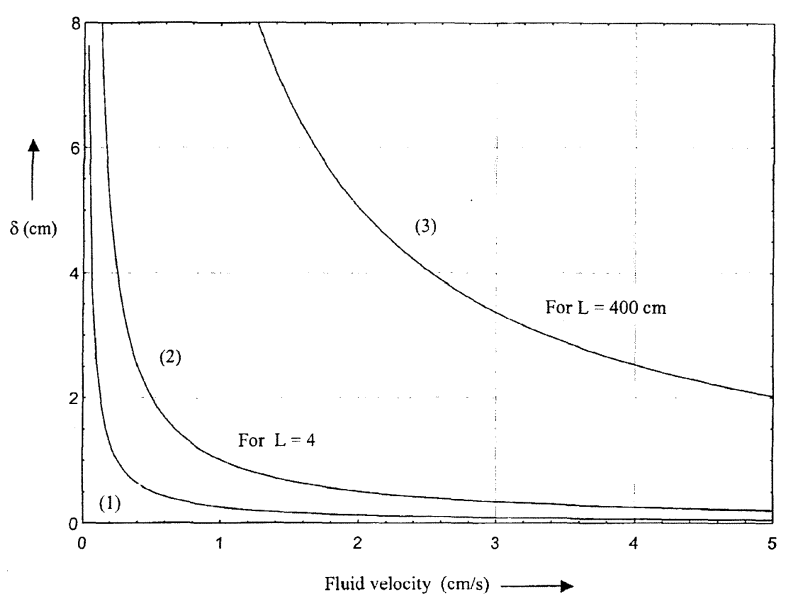

Figure 8. Variations in thickness of the boundary layer as a function of the fluid velocity (pig-iron at $1380^{\circ} \mathrm{C}$ ) in relation to the refractory interface.

1. Variation in thickness in the nodal boundary layer $d(v$, nodal $x / y)$.

2. Variation in the thickness of the velocity boundary layer $d(v)$ when the characteristic linear dimension of the system is $4 \mathrm{~cm}$. 3. Variation in the thickness of the velocity boundary layer $\mathrm{d}(\mathrm{v})$ when the characteristic linear dimension of the system is $400 \mathrm{~cm}$.

Figura 8. Variación de los espesores de la capa límite en función de la velocidad del fluido (arrabio a $1.380^{\circ} \mathrm{C}$ ) con respecto la intercara refractaria.

1. Variación del espesor de la capa límite nodal div, nodal $x / y)$.

2. Variación del espesor de la capa límite de velocidades $d(v)$ cuando la dimensión lineal característica del sistema es $4 \mathrm{~cm}$.

3. Variación del espesor de la capa límite de velocidades $d(v)$ cuando la dimensión lineal característica del sistema es $400 \mathrm{~cm}$.

The NWM, is not only an alternative to control the wear of the hearth of a blast furnace but, from an engineering and materials design perspective, it also makes valuable and original considerations regarding the variables that promote wear of the material. In the same way, it will be of interest to all the industries related with design and fabrication of new material working in contact with aggressive mediums.

Although it is not considered in this work, the mechanical fracture due to thermal shock of the refractory (which means an instant penetration of the fluid and failure of the hearth) may be studied attending to the thermal criterion indicated in the model. Independently from the fact a chemical corrosion or materials failure happens, at a determined node of the pig-iron - refractory interface, the temperature of the node and the one of nodes in its proximity, will determine wether accumulate stresses at the node are higher or not than the materials critical fracture stress, or if 
forces due to abrasive particles floating in the fluid are capable of surpassing the stiffness of the material at the considered node.

\section{ACKNOWLEDGMENTS}

The authors would like to thank the Ministerio de Ciencia y Tecnología ( Spain), MCYT (MAT 2000-1715) and the Vicerrectorado de Relaciones Internacionales of the Universidad de Oviedo the financing awarded to make the present publication possible.

\section{REFERENCES}

[1] A. Formoso, A. Gores, A.I. Babich, H.W. Gudenau, L. GarcíA, S. YAROSHEVSKII and J.L. MenÉndeZ, Rev. Metal. Madrid, 37 (2001) 423-436.

[2] A.I. Babich, HW. Gudenau, K.T. Mavrommatis, C. Froehling, A. Formoso, A. Cores and L. García, Rev. Metal. Madrid, 38 (2002) 288-305.

[3] R. Álvarez, J.L. García-Cimadevilla, M.A. Díez, J. Bermúdez, V. Alonso and E. Puente, Rev. Metal. Madrid, 38 (2002) 380-387.

[4] R.A. McCauley, Corrosion of Ceramics, Editorial Marcel Dekker, New York, 1995, pp. 7-82.

[5] E. Otero, Corrosión y degradación de materiales, Síntesis, Madrid, 1997, pp. 342-365.

[6] S. BANERJEE, Monolithic refractories: A comprehensive handbook, American Ceramic Society, Westerville, USA, 1998, pp. 219-242.

[7] M. Gutiérrez, Ma .F. Barbés, C. GoñI, A. Alfonso, R. PARra and L.F. VerdejA, VII Congreso Nacional de Propiedades Mecánicas de Sólidos, Gandía, 2002, pp. 539-544.

[8] R. Cooper and W.D. Kingery, J. Am. Ceram. Soc. 1 (1964) 37-43.

[9] B.N. SamadDar, W.D. Kingery and A.R. COOPER, J. Am. Ceram. Soc. 5 (1964) 249-254.

[10] Y. OISHI, A.R. COOPER and W.D. KingerY, J. Am. Ceram. Soc. 2 (1965) 88-95.

[11] P. Hrma, Verres Refract. 4-5 (1970) 166-168.

[12] L.F. Verdeja, A. Alfonso, R. GonzÁlez and J.L. Barranzuela, Rev. Minas (RDM), 13-14 (1996) 109-117.

[13] L.F. Verdeja, P. Rusek, A. Alfonso and R. GonZÁlez, Rev. Metal. Madrid, 34 (1998) 175-178.

[14] L.F. Verdeja, A. Alfonso, P. Rusek and J.L. BARRANZUELA, Application of FEM control wear of materials in the crucible blast furnace, Ed. INTEMIN (Instituto de Tecnología Minera)-SEGEMAR, Buenos Aires, 1997, pp. 341-344.

[15] L.F. Verdeja, A. Alfonso and R. González, Am. Ceram. Soc. Bull. 5 (1998) 91-96.
[16] D.R. POIRIER and E.J. POIRIER, Heat transfer fundamentals for metal casting, Editorial TMS, Warrendale, Pennsylvania ,USA, 1992, pp. 13-24; 30-40.

[17] A.J. Chapman, Heat transfer, Collier McMillan International Edition, $3^{\mathbf{a}}$ ed., New York, 1967, pp. 268 $275 ; 378-386$.

[18] D.R. POIRIER and G.H. GEIGER, Transport phenomena in materials processing, TMS, Warrendale, Pennsylvania, USA, 1994, pp. 247-369.

[19] J.L. Barranzuela, Tesis Doctoral, Escuela Técnica Superior de Ingenieros de Minas, Universidad de Oviedo, 2000.

[20] L.F. Verdeja, A. Alfonso and R. GonzÁlez, IV Conferencia sobre Simulación por Computadora e Inteligencia Artificial, S. Raczynski (ed.), Ciudad de México, Febrero 1988, pp. 44-51.

[21] H.J. Bachhofen, W. Kowalski, M. Peters and P. RÜTHER, Iron Steelmaker 6 (1999) 39-45.

[22] H.B. Lüngen, H.P. Rüther, G. Clixby and G. CAssella, Investigation blast furnace wear phenomena especially in the hearth, European Commission Technical Steel Research. EUR 19347 EN, Luxembourg, 2000, p. 193.

[23] K. Mülheims, W.D.N. Pritchard, J.M. Steiler and M. SCHULTE, Wear of blast furnace hearth, European Commission Technical Steel Research. EUR 20109 EN, Luxembourg, 2002, p. 272.

[24] D. JAMESON, H.B. LÜNGEN and D. LAO, Technical study into the means of prolonging furnace campaign life, European Commission Technical Steel Research. EUR 17247 EN, Luxembourg, 1997, p. 133.

[25] V. SCHULz and H. RÜTHER, Untersuchungen zur roheisenströmung in hochofengestell und abstichoptimierung, insbesondere zur verschleibminderung vermeidung von durchlerüchen, European Commission Tecnical Steel Research. EUR 16017 DE, Luxembourg, 1997, p. 139.

[26] T. Matsumoto, H. Marushima, H. Nishimura, K. YANAGiSAWA and N. NishimURA, Rev. Métall.-CIT 93 (1996) 379-389.

[27] M.J. Venturini, J.P. Bolsigner and J. Iezzi, 57th Ironmaking Conference Proc., Vol. 57, Toronto (Canadá), Iron and Steel Society, Warrendale, Pennsylvania (USA), 1998, pp. 615-662.

[28] W. KowAlski, H.J. BaChHOFen and H.P. Rüther, 57th Ironmaking Conference Proc., Vol. 57, Toronto (Canadá), Iron and Steel Society, Warrendale, Pennsylvania (USA), 1998, pp. 595-605.

[29] M. Schulte, R. Klima, D. Ringel and M. Voss, 57th Ironmaking Conference Proc., Vol. 57, Toronto (Canada), Iron and Steel Society, Warrendale, Pennsylvania (USA), 1998, pp. 607-614.

[30] M. Schulte, R. Klima, D. Ringel and M. Voss, Stahl Eisen, 11 (1997) 57-63.

[31] G. SÁnchez, P. Etchevarne and P. Partemio, iasCRISOL: Sistema computacional para la simulación de la transferencia de calor en crisoles de altos hornos, Report restricted for the Argentine Institute of Iron and Steel Industry and SIDEMAR S.A. SOFT-ING, Buenos Aires (Argentina) 1997. 